\title{
Factors related to non-adherence to mammography in a city of the Brazilian Amazonian area: A population-based study
}

Camila Iasmim de Andrade Souza ${ }^{1}$, Daniela Souza Araújo ${ }^{1}$, Daniele Aparecida de Freitas Teles ${ }^{1}$, Stéphanie Gomes Lins de Carvalho ${ }^{1}$, Kyldery Wendell Moura Cavalcante ${ }^{1}$, Wendell lima Rabelo ${ }^{1}$, Cibelli Navarro Rodrigues Alves ${ }^{2}$, Allex Jardim da Fonseca ${ }^{3 *}$

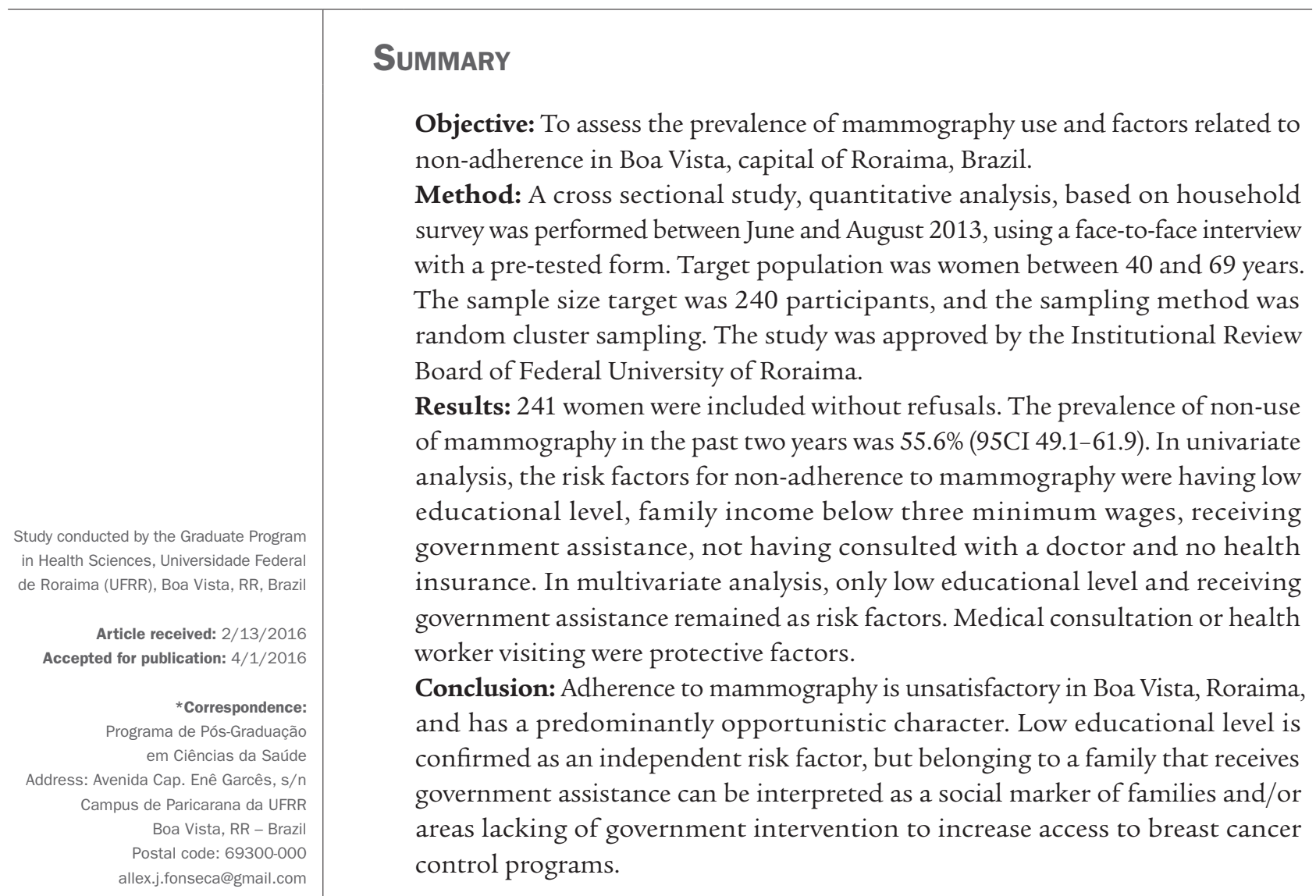

Keywords: mammography, mass screening, breast neoplasm, health services coverage.

\section{INTRODUCTION}

Although the incidence of breast cancer is higher in economically developed countries, higher mortality rates have been registered in underdeveloped countries, such as Brazil. ${ }^{1,2}$ There is also a time trend increasing this discrepancy. While a reduction to the order of 11 absolute percentage points in breast cancer-specific mortality has been observed in the United States between 2001 and $2009,{ }^{3}$ the data indicates an increase in mortality from this disease in Brazilian women over the last three decades in almost all age groups, especially younger individuals (up to 50 years of age). ${ }^{2,4}$ According to the National Cancer Institute (INCA), in 2014 there were approximately 16 deaths per 100,000 women in Brazil. ${ }^{2}$

Countries and regions that have been able to reduce breast cancer mortality credit this decline to the use of more effective therapies associated with large population screening programs for early detection of the disease. Indeed, the initial extent of the disease is the main predictor of survival in women affected by breast cancer. ${ }^{5}$ In countries whose breast cancer screening programs are inefficient or scarce, most women are diagnosed at advanced stages of 
the disease and the overall five-year survival rate is relatively low. ${ }^{6-8}$ On the other hand, in regions with large scale screening programs a reduction in breast cancer mortality ranging from 15 to $30 \%$ has been reported. ${ }^{7,9,10}$

Adherence to mammography-based screening, in turn, suffers multifactorial influences, such as cultural, social and economic issues, public knowledge about the disease and the examination, and the provision of mammography exams in the public and private sectors. ${ }^{11-14}$ Despite the control of breast cancer having been included among the priorities of the Brazilian Health Pact, ${ }^{15}$ the estimated mammography coverage obtained via household surveys shows insufficient and unequal screening in Brazilian regions. ${ }^{12,16,17}$ In a country as heterogenous as Brazil, regional studies can demonstrate variations in the determinant factors of mammography adherence, propitiating adjustments to preventive strategies in accordance with local characteristics. The aim of this study is to assess the prevalence of the use of mammographic screening and the factors related to non-adherence in Boa Vista, the capital of the state of Roraima, in the Brazilian Amazon area.

\section{Method}

\section{Study design}

This is a cross-sectional, observational study with a quantitative analysis, based on household survey of a random sample in the municipality of Boa Vista, designed to assess women's adherence to breast cancer screening examinations, as well as demographic characteristics, between June and August 2013.

\section{Setting and population of the study}

The study was conducted in the municipality of Boa Vista, the capital of the state of Roraima, located within the Legal Amazon, in Northern Brazil. With a population of approximately 285,000 inhabitants, the municipality of Boa Vista concentrates approximately $65 \%$ of the state population, and has a Family Health Program (PSF, in the Portuguese acronym) that covers $75 \%$ of its population. The target population of the survey was women between 40 and 69 years of age resident in the municipality of Boa Vista for at least two years.

\section{Sampling}

The sample size was calculated considering the expected prevalence of $60 \%$ coverage for cancer screening, based on a national telephone survey conducted in $2008,{ }^{18}$ assuming a normal distribution for the desired confidence interval of $95 \%$ and an acceptable error of $5 \%( \pm 2.5 \%)$, leading to a sample size of at least 240 individuals.
The sampling method was randomized by conglomerate, considering city blocks as the sample conglomerates. There are 4,902 blocks that make up the districts in the urban zone of the municipality of Boa Vista. These were listed and drawn by software, producing a random number sequence (http://www.random.org). The random selection of the blocks was weighted by population size and the number of registered households in each epidemiological zone of the municipality.

\section{Research procedures}

All households in the first 25 blocks selected were visited, and female residents belonging to the target age group were approached in their homes during the early morning or evenings on weekends, and invited to participate in the study by signing the informed consent form. Data collection took place between June and August 2013.

We included women aged between 40 and 69 years, since the recommendation at the time was to not exclude younger women from screening (40 to 49 years). The study excluded women who were present but did not reside at the household, who were outside of the age range, who had resided in another municipality in the last two years, and those who did not accept participation in the research. If the resident woman was not at home at the time of the visit, the researcher would return to the residence the following week. In the case of a second absence, the woman was excluded. If the sample goal was not reached in the first 25 blocks visited, another five blocks would be drawn, using the same method successively until the sampling goal was achieved.

A semi-structured form was used as a research tool instrument, with open and closed questions, prepared by the authors, and previously tested to evaluate descriptive and explanatory variables such as age, education, marital status, socioeconomic data, government aid, health agent visits, and history of medical visits. The form was answered via a face-to-face interview at the volunteer's home, preferably in the absence of the volunteer's cohabitants, and for a maximum of 30 minutes. The outcome variable assessed was non-adherence to the breast cancer screening program, defined as failure to undergo at least one mammogram in the last two years prior to the date of the interview, regardless of the outcome of the test and where it was conducted.

\section{Quality control}

After the completion of the fieldwork, $10 \%$ of the forms obtained by each interviewer were selected for quality control. The patients were re-interviewed by the principal in- 
vestigator, via telephone, referring to what were considered key questions. Responses to the key questions were compared to those obtained in the first phase of the field research. In the event of disagreement greater than $5 \%$ between the responses of at least one volunteer, all observations collected by the stated researcher were to be discarded.

\section{Statistical analysis}

A descriptive statistical analysis was performed, including the frequency distribution for categorical variables, and the means (with standard deviation) for continuous variables with normal distribution. The prevalence of the outcome variable (non-adherence to the use of mammography) and its $95 \%$ confidence interval (95CI) were estimated based on binomial distribution. For comparison of the sample means, Student's t-test was used for variables with a normal distribution and homogeneity of sample variances. Otherwise, the Mann-Whitney U test was used for this purpose. We used Chi-squared test to compare differences in the proportions of categorical variables. Odds ratio (OR) and 95CI were calculated in a univariate analysis and the adjusted odds ratio (aOR) was calculated in a multivariate analysis by logistic regression. The selection criteria of the explanatory variables for input into the multivariate analysis was a critical value of $\mathrm{p}<0.15$ in the univariate analysis. The level of statistical significance was set at $5 \%$. The information was analyzed after double data entry and the databases were compared to detect data entry errors. The statistical analyses were conducted using EpiInfo ${ }^{\circledR}$ software, version 7.1 for Windows (CDC, Atlanta, US).

\section{Ethical aspects}

The study was approved by the Committee for Research Ethics involving humans at the Federal University of Roraima (report no. 111,007 of 2013). All of the adult women volunteers approached were fully clarified as to the purposes and methods of the research and signed the consent form before the interview. The documents were coded rather than being identified. At the end of the interview, all the volunteers were given an explanatory folder on breast cancer, the importance of mammography, and the health facility where it can be conducted. The leaflets distributed were purchased from the State Health Department and are part of the publicity material of the Ministry of Health of Brazil.

\section{RESULTS}

Two hundred forty-one (241) female residents of the 30 blocks in the municipality of Boa Vista, Roraima, were interviewed, without refusals or loss of data. The average age was 48.3 years $( \pm 5.3)$, and approximately one third of the sample was between 40 and 44 years of age. The marital status reported the most was married/common-law partner $(\mathrm{n}=127 ; 52.7 \%)$. None of the participants were illiterate, and the most frequent education levels were up to the primary level ( $\mathrm{n}=93 ; 38.6 \%)$ and secondary level $(\mathrm{n}=93 ; 38.6 \%)$. Most of the women studied did not have private health plans $(\mathrm{n}=199 ; 84.0 \%)$, but most participants reported having consulted a physician within the past year $(\mathrm{n}=202 ; 85.3 \%)$. The average household income reported was BRL 2,016 (approximately three minimum wages at the time of the study). Most women had a household income of less than BRL 2,000 ( $\mathrm{n}=155 ; 64.4 \%)$. The average number of family cohabitants was $4.0( \pm 1.8)$. Less than half of the participants reported receiving social aid from the government $(\mathrm{n}=105$; 44.3\%) or receiving a health agent visit (Family Health Strategy) within the past year $(\mathrm{n}=59 ; 24.9 \%)$. Table 1 describes the demographic characteristics of the sample.

One hundred forty-eight (148) women of the 241 participants analyzed $(61.4 \%)$ reported having carried out a mammogram at some point in their life. Only 107 women (44.4\%) reported having undergone the examination within the last two years. Therefore, the prevalence of non-use of mammography for breast cancer screening in the past two years was 55.6\% (95CI 49.1-61.9). There was a trend towards lower use of mammography in younger women (40 to 49 years) compared with those aged 50 years or more (60.4 vs. 49.5\%, respectively), without statistical significance.

Marital status was not correlated with greater or lesser adherence to screening with mammography. With regard to education, non-use of the examination was significantly higher for women with a low educational level in relation to those with undergraduate/graduate education. For women who reported education up to primary level, most of them did not undergo the examination $(67.8 \%, \mathrm{p}=0.005)$, generating an OR 2.19 (95CI 1.26-3.81). For those that reported higher education, the prevalence of non-use was limited to $34.5 \%$ ( $\mathrm{p}<0.0001$ ), reducing the likelihood of non-use to a third (OR 0.32, 95CI 0.17-0.61). The average level of education was not correlated with greater or lesser adherence to breast cancer screening. Table 2 details the results of the univariate analysis.

It should be noted that the reported household income was also correlated with adherence to the preventive examination in the univariate analysis. Women with a reported income of less than BRL 2,000 (three minimum wages at the time of the study) showed higher prevalence of non-use of mammography than those with an income of more than BRL 4,000 (65.8 vs. $27.9 \%$, respectively; $\mathrm{p}<0.0001$ ). In this analysis, income of less than three minimum wages 
more than tripled the chance of not having undertaken a mammogram in the previous year (OR 3.24, 95CI 1.87 -5.62 ). Having private health insurance was shown to be a protective factor. Non-use of the exam was two times lower in women insured by a health plan than in uninsured women ( 28.9 vs. $60.6 \%$, respectively, $\mathrm{p}=0.0006$; OR 0.26 , 95CI 0.12-0.56). On the other hand, receiving government aid (social benefits) represented a risk factor for nonadherence to breast cancer screening (OR 3.46, 95CI 2.01 -5.96). Attending a medical consultation (for another reason) over the past year represented an important protective factor, substantially reducing the chance of non-adherence to mammography (OR 0.16, 95CI 0.06-0.43). It should be noted that $86 \%$ of the participants who did not report a medical consultation in the past two years also did not undertake a mammogram during that period. Having received a visit by a health agent and number of cohabiting family members were not correlated with the outcome studied (Table 2).

The variables that presented a significant correlation or tendency to correlate with the outcome in the univariate analysis $(\mathrm{p}<0.15)$ were reevaluated in a multivariate analysis in order to detect confounding factors. In this analysis, the only variables that remained risk factors for non-adherence to breast cancer screening were low level of education and receiving government aid. Women with education restricted to the primary level presented a likelihood of non-use of mammography that was almost twice as high (adjusted OR 1.98, 95CI 1.48-3.05) in relation to women with a higher level of education. Receiving government aid also doubled the chance of non-use of mammography (adjusted OR 2.27, 95CI 1.14-4.52). Consulting a physician in the past year (adjusted OR 0.16, 95CI 0.05-0.46) and receiving health agent visits (adjusted OR 0.43 , 95CI $0.22-0.85$ ) were confirmed as protective factors, both significantly reducing the chance of not undertaking a mammogram. Age, income, and health plan variables were not sustained as independent risk factors in the multivariate analysis (Table 3).

\section{Discussion}

Although occasionally recommended by national and international guidelines, early detection strategies other than mammography fail to demonstrate effectiveness in reducing breast cancer mortality. Breast self-examination is not advocated by INCA and other organizations as there is no evidence of this measure's benefits in terms of reducing mortality. ${ }^{19,20}$ Clinical examination of the breast is recommended because it is a part of medical semiology. However, it has substantially less diagnostic accuracy than mammography for early breast cancer investigation, and no impact on the reduction of mortality. ${ }^{21,22}$ For these reasons, information on self-examination or clinical breast examination were omitted from our study.

Mammography is the only strategy capable of reducing breast cancer mortality (estimated decrease of 30\%) in women over 50 years of age regularly screened every 24 months. ${ }^{22-24}$ For younger women (< 50 years), the effectiveness of mammograms is controversial because it is related more with an increase in costs from unnecessary interventions than with reduced mortality. ${ }^{25}$ During the agreement of the goals for the control of breast cancer in 2006, the Ministry of Health of Brazil recommended a biennial mammogram for women aged 50 to 69 years and an annual clinical breast examination for those aged between 40 and 49 years. ${ }^{15}$ However, Law N. 11.664/2008 assured mammograms for all women aged over 40 years. ${ }^{26}$ In November 2013, after the collection of data in this survey, Ministry of Health Ordinance N. 1253 modified access, ${ }^{27}$ maintaining the guarantee of screening mammography only for women between 50 and 69 years of age, limiting mammography to unilateral diagnosis in women aged between 40 and 49 years.

The present study was a pioneer in the assessment of factors related to the use of mammographic investigation for screening for early breast cancer in the North region of Brazil. In our study, the prevalence of non-adherence was $55.6 \%$, which is higher than the non-adherence rates observed in other household surveys in Brazil. Marchi et al. ${ }^{28}$ conducted a study that surveyed 460 women in the city of Taubaté, São Paulo, served at public and private health services in 2010. The authors reported a prevalence of non-adherence to mammography of $32 \%$ in the last 24 months. Another similar study, ${ }^{29}$ conducted in Pelotas, Rio Grande do Sul, analyzed 879 women aged 40 to 69 years, and revealed that $30 \%$ of those interviewed had not undergone a mammogram (in the last two years). The coverage assessed by our study was shown to be heterogeneous and influenced by socioeconomic factors. We found that women with a higher level of education presented a greater chance of undergoing mammography: attaining the secondary level of schooling led to a $15 \%$ gain. Higher education produced a gain of more than $30 \%$ compared to primary level. Something similar was reported by Oliveira et al., who analyzed data from National Household Sample Survey - PNAD 2003 and 2008. ${ }^{30}$ In their study assessing secondary data, albeit nationwide, $54.6 \%$ of women aged 50 to 69 years reported having undergone mammograms in 2003, and $71.5 \%$ in 2008. The chance of conducting an examination increased with 
household income and level of education. The authors reported that having more than ten years of study tripled the chance of conducting a mammogram compared to those not formally educated.

Factors related to non-adherence also vary among the regions studied. In a study by Sclowitz et al. ${ }^{29}$ (Pelotas, 2005), the factors related the most to not undertaking mammograms were low social class, lack of family history of breast cancer, and not having had a gynecological consultation in the period assessed. In a study by Oliveira et al., ${ }^{30}$ the risk factors highlighted included age over 70 years, being single, having a low income, not having health insurance, not having carried out consultations with a physician in the past 12 months, living in rural areas or in the North Region of the country. Meanwhile, in a study by Marchi et al. ${ }^{28}$ (Taubaté, 2010), the factors related to non-adherence included being an exclusive user of the SUS (Brazilian public health system), irregular gynecological consultations, and never having undergone a previous mammogram. Corroborating the findings of our study, it can be seen that having a consultation with a physician is one of the main protective factors for undergoing a mammogram, suggesting that breast cancer screening is still mostly opportunistic in Brazil. The influence of medical

TABLE 1 Demographic characteristics of the sample studied ( $n=241)$.

\begin{tabular}{|c|c|c|}
\hline Variable & Average $( \pm S D)$ & n (\%) \\
\hline Age (years) & $48.3( \pm 5.3)$ & \\
\hline 40 to 44 years & & $78(32.4 \%)$ \\
\hline 45 to 49 years & & $56(23.2 \%)$ \\
\hline 50 to 54 years & & $71(29.5 \%)$ \\
\hline$\geq 55$ years & & $36(14.9 \%)$ \\
\hline \multicolumn{3}{|l|}{ Marital status } \\
\hline Single & & $67(27.8 \%)$ \\
\hline Married/common-law partner & & $127(52.7 \%)$ \\
\hline Divorced/separated/widowed & & $47(19.5 \%)$ \\
\hline \multicolumn{3}{|l|}{ Education } \\
\hline Illiterate & & 0 \\
\hline Primary school & & $93(38.6 \%)$ \\
\hline High school & & $93(38.6 \%)$ \\
\hline Higher education/postgraduate & & $55(22.8 \%)$ \\
\hline \multicolumn{3}{|l|}{ Has insurance/health plan } \\
\hline Yes & & $38(16.0 \%)$ \\
\hline No & & $199(84.0 \%)$ \\
\hline Household income (BRL) & $2,016.24( \pm 2,145.03)$ & \\
\hline$<$ BRL 2,000 & & $155(64.4 \%)$ \\
\hline Between BRL 2,000 and BRL 4,000 & & $51(21.1 \%)$ \\
\hline$>\mathrm{BRL} 4,000$ & & $35(14.5 \%)$ \\
\hline Cohabiting family members ( $n$ ) & $4.0( \pm 1.8)$ & \\
\hline$>4$ family members & & $81(34.2 \%)$ \\
\hline Up to 4 family members & & $156(65.8 \%)$ \\
\hline \multicolumn{3}{|l|}{ Government aid } \\
\hline Receiving & & $105(44.3 \%)$ \\
\hline Not receiving & & $132(55.7 \%)$ \\
\hline \multicolumn{3}{|l|}{ Medical consultation in the past year } \\
\hline Yes & & $202(85.3 \%)$ \\
\hline No & & $35(14.7 \%)$ \\
\hline \multicolumn{3}{|l|}{ Health agent visit } \\
\hline Yes & & $59(24.9 \%)$ \\
\hline No & & $178(75.1 \%)$ \\
\hline
\end{tabular}


TABLE 2 Univariate analysis for evaluation of non-adherence to mammographic screening over the last two years in the municipality of Boa Vista, Roraima, 2013.

\begin{tabular}{|c|c|c|c|c|c|c|}
\hline \multirow[t]{2}{*}{ Explanatory variable } & \multirow[t]{2}{*}{ Total } & \multicolumn{2}{|c|}{ MMG not conducted in the last 2 years } & \multirow[t]{2}{*}{ p-value } & \multirow[t]{2}{*}{ Odds ratio } & \multirow[t]{2}{*}{$95 \mathrm{Cl}$} \\
\hline & & $\mathbf{n}$ & $\%$ & & & \\
\hline \multicolumn{7}{|l|}{ Age } \\
\hline Between 40 and 49 years & 134 & 81 & 60.4 & ns & 1.57 & $0.93-2.60$ \\
\hline 50 years or older & 107 & 53 & 49.5 & & 1 & \\
\hline \multicolumn{7}{|l|}{ Marital status } \\
\hline Single & 67 & 41 & 61.2 & ns & 1.37 & $0.77-2.44$ \\
\hline Married & 127 & 66 & 51.9 & ns & 0.73 & $0.43-1.22$ \\
\hline Widowed/divorced & 47 & 27 & 57.5 & ns & 1.09 & $0.57-2.08$ \\
\hline \multicolumn{7}{|l|}{ Education } \\
\hline University & 55 & 19 & 34.5 & $<0.0001$ & 0.32 & $0.17-0.61$ \\
\hline High school & 93 & 59 & 53.7 & ns & 0.88 & $0.52-1.49$ \\
\hline Primary school & 84 & 57 & 67.8 & 0.005 & 2.19 & $1.26-3.81$ \\
\hline \multicolumn{7}{|l|}{ Household income } \\
\hline$<$ BRL 2,000 & 155 & 102 & 65.8 & $<0.0001$ & 3.24 & $1.87-5.62$ \\
\hline Between BRL 2,000 and 4,000 & 43 & 20 & 46.5 & ns & 0.64 & $0.33-1.24$ \\
\hline$>$ BRL 4,000 & 43 & 12 & 27.9 & 0.0001 & 0.24 & $0.11-0.49$ \\
\hline \multicolumn{7}{|l|}{ Has health insurance } \\
\hline Yes & 38 & 11 & 28.9 & 0.0006 & 0.26 & $0.12-0.56$ \\
\hline No & 203 & 123 & 60.6 & & 1 & \\
\hline \multicolumn{7}{|l|}{ Cohabiting family members } \\
\hline$>4$ family members & 83 & 53 & 63.8 & ns & 1.67 & $0.97-2.89$ \\
\hline Up to 4 family members & 158 & 81 & 51.2 & & 1 & \\
\hline \multicolumn{7}{|l|}{ Government aid } \\
\hline Receiving & 107 & 77 & 71.9 & $<0.0001$ & 3.46 & $2.01-5.96$ \\
\hline Not receiving & 134 & 57 & 42.5 & & 1 & \\
\hline \multicolumn{7}{|l|}{ Medical consultation } \\
\hline Yes & 205 & 103 & 50.2 & 0.0001 & 0.16 & $0.06-0.43$ \\
\hline No & 36 & 31 & 86.1 & & 1 & \\
\hline \multicolumn{7}{|l|}{ Health agent visit } \\
\hline Yes & 61 & 28 & 45.9 & ns & 0.59 & $0.33-1.06$ \\
\hline No & 180 & 106 & 58.9 & & 1 & \\
\hline
\end{tabular}

MMG: mammogram; ns: not significant ( $p$-value > 0.05); 95Cl: 95\% confidence interval.

TABLE 3 Multivariate analysis for non-adherence to mammographic screening in the municipality of Boa Vista, Roraima, 2013.

\begin{tabular}{llll} 
Variable & Adjusted odds ratio & $\mathbf{9 5 C l}$ & $\mathbf{P}$-value \\
\hline Age between 40 and 49 years & 1.64 & $0.90-2.99$ & $\mathrm{~ns}$ \\
\hline Primary school only & 1.98 & $1.48-3.05$ & 0.008 \\
\hline Higher education & 0.96 & $0.39-2.34$ & $\mathrm{~ns}$ \\
\hline Household income less than BRL 2,000 & 1.33 & $0.55-3.22$ & $\mathrm{~ns}$ \\
\hline Household income higher than BRL 4,000 & 0.49 & $0.18-1.35$ & $\mathrm{~ns}$ \\
\hline Having health insurance & 0.52 & $0.20-1.32$ & $\mathrm{~ns}$ \\
\hline Receiving government aid & 2.27 & $1.14-4.52$ & 0.01 \\
\hline Having a medical consultation in the past year & 0.16 & $0.05-0.46$ & 0.0007 \\
\hline Having been visited by a health agent & 0.43 & $0.22-0.85$ & 0.01 \\
\hline
\end{tabular}

ns: not significant ( $\mathrm{p}$-value > 0.05); 95Cl: $95 \%$ confidence interval. 
advice has also been reported in other countries. A cross-sectional study conducted in the United States ${ }^{31}$ in the year 2000 and involving 1,301 women found that medical advice is the variable most strongly associated with the use of mammography. Women who reported medical advice were more likely to adhere to breast cancer screening. The impact of medical advice was so important that the authors postulated a model of increased use of mammography in two stages: first, public call; and secondly, individual encouragement by the physician. Another North American study ${ }^{32}$ specifically assessed the importance of medical communication on adherence to mammography among 972 women over 50 years of age. A 4.5 times greater propensity to performing mammography was reported among women who received encouragement from their physicians with respect to the benefits of the examination. The authors concluded that the key to increasing the coverage of breast cancer screening is improved communication skills between physicians and patients.

It is interesting to note that a visit from a health care agent was also correlated with adherence to mammography in our study, highlighting the importance of professional advice in the promotion of health in this sample. We noted that among women who had not consulted a physician in the past two years, the prevalence of non-adherence was very high, at $86 \%$. This indicates two main scenarios: difficult access to the examination by spontaneous demand and poor public knowledge about the importance of the examination, which may have been minimized via medical consultations in the period. A survey that assessed women's knowledge about the subject ${ }^{33}$ (São Paulo, 2011) revealed that the subject of "breast cancer" is well-known to women, but mammography still needs to be clarified in relation to its objectives and recommendations, representing a possible barrier to satisfactory coverage of the population screening.

Another important fact was the demonstration of education level as an independent determinant of the use of mammography, overlapping with income in the multivariate analysis. Although the study by Sclowitz et al. ${ }^{29}$ found a correlation between low social class and nonperformance of the examination, the authors' evaluation did not include the numerous characteristics defining social class. In our study, reaching secondary education attributed a gain of $15 \%$, while higher education led to a gain of $30 \%$ compared to women with primary educational level, meaning that more years of schooling was confirmed as an independent protection factor. In relation to the receipt of social benefits, despite the correlation not being statistically significant in the univariate analy- sis, this variable was established as an independent risk factor in the multivariate analysis. Although this variable might at first be interpreted merely as a confounding factor, it should be analyzed as a social marker, as it represents easily identified registered families, assisting health managers in the zoning of areas most in need of government intervention.

This study has limitations. Firstly, the conglomerate sampling method used might fail to make the sample accurately representative of the population studied. Secondly, the cross-sectional design presupposes not allowing the use of temporality as a criterion for causality, given that the risk factors and outcome were measured at the same time and the bias of reverse causality cannot be eliminated. Finally, studies based on face-to-face interviews are susceptible to the masking of answers, especially with the subject of personal health. However, the sample size and the robustness of the research procedures adopted strengthen the reliability of the data.

\section{Conclusion}

The coverage of breast cancer screening using mammography is unsatisfactory in Boa Vista (RR), and has an opportunistic character because of its correlation with a background of medical consultations and health agent visits over the last two years. A low level of educational is confirmed as an independent risk factor for non-adherence to screening, and belonging to a family that receives government aid can be interpreted as a social marker of families and/or areas lacking government intervention in order to increase access to breast cancer control programs.

\section{Conflict of interest}

The authors declare no conflict of interest.

\section{AcKnowledgments}

We would like to thank the Cooperativa Múltiplos em Saúde (Boa Vista - Roraima) for its financial support for the implementation of the field research in this study.

\section{Resumo}

Fatores relacionados à não utilização de mamografia em capital brasileira da região Norte: um estudo de base populacional

Objetivo: Avaliar a prevalência de utilização da mamografia e fatores relacionados à não adesão em Boa Vista, capital de Roraima, Brasil. 
Método: Trata-se de um estudo de corte transversal, de análise quantitativa, baseado em inquérito domiciliar, por entrevista face a face, utilizando formulário previamente testado. Foram incluídas mulheres entre 40 e 69 anos, entre junho e agosto de 2013. A meta amostral foram 240 participantes, e o método de amostragem foi aleatório por conglomerado. O estudo foi aprovado pelo Comitê de Ética em Pesquisa da Universidade Federal de Roraima. Resultados: 241 mulheres foram incluídas, sem recusas. A prevalência de não utilização de mamografia nos últimos dois anos foi 55,6\% (IC95\% 49.1-61.9). Em análise univariada, os fatores de risco para não adesão à mamografia foram baixa escolaridade, renda familiar inferior a três salários mínimos, receber auxílio governamental, não ter sido consultado por médico e não ter plano de saúde. Em análise multivariada, apenas baixa escolaridade e receber auxílio governamental se mantiveram como fatores de risco, enquanto consulta médica ou visita de agente de saúde, como fatores de proteção independentes.

Conclusão: A adesão à mamografia é insatisfatória em Boa Vista e tem caráter predominantemente oportunista. Baixa escolaridade se confirma como fator de risco independente, mas pertencer a uma família que recebe auxílio governamental pode ser interpretado como marcador social das famílias e/ou áreas mais carentes de intervenção governamental para aumentar o acesso aos programas de controle do câncer de mama.

Palavras-chave: mamografia, programas de rastreamento, neoplasias de mama, cobertura dos serviços de saúde.

\section{RefEREnCES}

1. DeSantis C, Ma J, Bryan L, Jemal A. Breast cancer statistics, 2013. CA Cancer J Clin. 2014; 64(1):52-62.

2. Brasil. Ministério da Saúde. Estimativa 2014: Incidência de câncer no Brasil. In: Saúde. Rio de Janeiro: INCA; 2014.

3. Ma J, Ward EM, Siegel RL, Jemal A. Temporal trends in mortality in the United States, 1969-2013. JAMA. 2015; 314(16):1731-9.

4. Martins CA, Guimarães RM, Silva RLPD, Ferreira APS, Gomes FL, Sampaio JRC, et al. [Evolution of breast cancer mortality in young woman: challenges to a policy of oncologic attention]. Rev Bras Cancerologia. 2013; 59(3):341-9.

5. Rosenberg J, Chia YL, Plevritis S. The effect of age, race, tumor size, tumor grade, and disease stage on invasive ductal breast cancer survival in the U.S. SEER database. Breast Cancer Res Treat. 2005; 89(1):47-54.

6. Bravo LE, García LS, Collazos PA. Cancer survival in Cali, Colombia: a population-based study, 1995-2004. Colomb Med (Cali). 2014; 45(3):110-6.

7. Ferlay J, Soerjomataram I, Dikshit R, Eser S, Mathers C, Rebelo M, et al Cancer incidence and mortality worldwide: sources, methods and major patterns in GLOBOCAN 2012. Int J Cancer. 2015; 136(5):E359-86.

8. Galukande $\mathrm{M}$, Wabinga $\mathrm{H}$, Mirembe $\mathrm{F}$. Breast cancer survival experiences at a tertiary hospital in sub-Saharan Africa: a cohort study. World J Surg Oncol. 2015; 13:220
9. Coldman A, Phillips N, Wilson C, Decker K, Chiarelli AM, Brisson J, et al Pan-Canadian study of mammography screening and mortality from breast cancer. J Natl Cancer Inst. 2014; 107(1):pii:dju261.

10. Kalager M, Zelen M, Langmark F, Adami HO. Effect of screening mammography on breast-cancer mortality in Norway. N Engl J Med. 2010; 363(13):1203-10.

11. Senicato C, Barros MBA. Social inequality in health among women in Campinas, São Paulo State, Brazil. Cad Saúde Pública. 2012; 28(10):1903-14.

12. Novaes CO, Mattos IE. Prevalência e fatores associados a não utilização de mamografia em mulheres idosas. Cad Saúde Pública. 2009; 25(Supl 2):s310-20.

13. Rodrigues JD, Cruz MS, Paixão AN. Uma análise da prevenção do câncer de mama no Brasil. Ciência Saúde Coletiva. 2015; 20(10):3163-76.

14. Lourenço TS, Mauad EC, Vieira RAC. Barreiras no rastreamento do câncer de mama e o papel da enfermagem: revisão integrativa. Rev Bras Enferm. 2013; 66(4):585-91.

15. Brasil. Ministério da Saúde. Pacto pela Saúde, 2006. Portaria no 399, de 22 fev 2006. Brasília; 2006

16. Amorim VMSL, Barros MBdA, César CLG, Carandina L, Goldbaum M. Fatores associados a não realização da mamografia e do exame clínico das mamas: um estudo de base populacional em Campinas, São Paulo, Brasil. Cad Saúde Pública. 2008; 24(11):2623-32.

17. Vieira RA, Lourenco TS, Mauad EC, Moreira Filho VG, Peres SV, Silva TB et al. Barriers related to non-adherence in a mammography breast-screening program during the implementation period in the interior of Sao Paulo State, Brazil. J Epidemiol Glob Health. 2015; 5(3):211-9.

18. Brasil. Ministério da Saúde. Vigitel Brasil 2008. Vigilância de fatores de risco e proteção para doenças crônicas por inquérito telefônico. Available from: http://bvsms.saude.gov.br/bvs/publicacoes/vigitel_brasil_2008.pdf.

19. Myers ER, Moorman P, Gierisch JM, Havrilesky LJ, Grimm LJ, Ghate S, et al. Benefits and harms of breast cancer screening: a systematic review. JAMA. 2015; 314(15):1615-34.

20. Brasil. Ministério da Saúde. Instituto Nacional do Câncer. Detecção precoce do câncer de mama. Rio de Janeiro, 2016. Available from: http://www2.inca.gov $\mathrm{br} / \mathrm{wps} / \mathrm{wcm} /$ connect/tiposdecancer/site/home/mama/deteccao_precoce.

21. Oeffinger KC, Fontham ET, Etzioni R, Herzig A, Michaelson JS, Shih YC, et al. Breast cancer screening for women at average risk: 2015 guideline update from the American Cancer Society. JAMA. 2015; 314(15):1599-614.

22. Fitzgerald SP. Breast-cancer screening - Viewpoint of the IARC Working Group. N Engl J Med. 2015; 373(15):1479.

23. Keen JD, Keen JE. What is the point: will screening mammography save my life? BMC Med Inform Decis Mak. 2009; 9:18.

24. Tabar L, Yen MF, Vitak B, Chen HH, Smith RA, Duffy SW. Mammography service screening and mortality in breast cancer patients: 20-year follow-up before and after introduction of screening. Lancet. 2003; 361(9367):1405-10

25. Silva FX, Katz L, Souza ASR, Amorim MMR. Mammography in asymptomatic women aged 40-49 years. Rev Saúde Pública. 2014; 48(6):931-9.

26. Brasil. Presidência da República. Lei no 11.664 , de 29 de abril de 2008. Available from: http://www.planalto.gov.br/ccivil_03/_ato2007-2010/2008/lei/111664.htm.

27. Brasil. Ministério da Saúde. Portaria n ${ }^{\circ} 1.253$, de 12 de novembro de 2013 Available from: http://bvsms.saude.gov.br/bvs/saudelegis/sas/2013/ prt1253_12_11_2013.html.

28. Marchi AA, Gurgel MS. [Adherence to the opportunistic mammography screening in public and private health systems]. Rev Bras Ginecol Obstet. 2010; 32(4):191-7.

29. Sclowitz ML, Menezes AMB, Gigante DP, Tessaro S. Condutas na prevenção secundária do câncer de mama e fatores associados. Rev Saúde Pública. 2005; 39(3):340-9.

30. Oliveira EXG, Pinheiro RS, Melo ECP, Carvalho MS. Condicionantes socioeconômicos e geográficos do acesso à mamografia no Brasil, 20032008. Ciênc Saúde Coletiva. 2011; 16(9):3649-64.

31. Hawley ST, Earp JA, O'Malley M, Ricketts TC. The role of physician recommendation in women's mammography use: is it a 2 -stage process? Med Care. 2000; 38(4):392-403.

32. Fox SA, Siu AL, Stein JA. The importance of physician communication on breast cancer screening of older women. Arch Intern Med. 1994; 154(18):2058-68

33. Santos GD, Chubaci RYS. O conhecimento sobre o câncer de mama e a mamografia das mulheres idosas frequentadoras de centros de convivência em São Paulo (SP, Brasil). Ciênc Saúde Coletiva. 2011; 16(5):2533-40. 